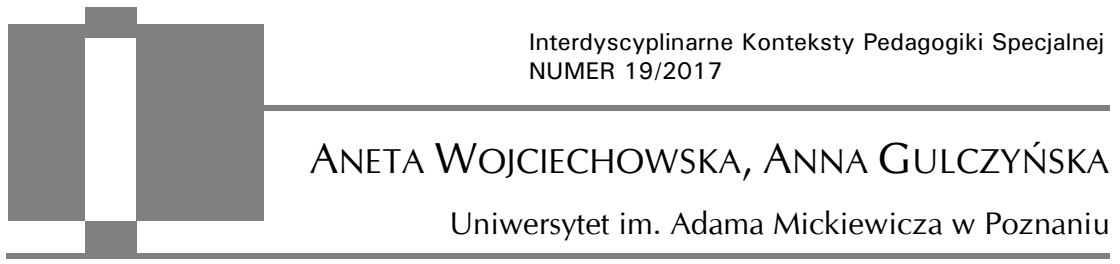

\title{
Zachowania seksualne dzieci i młodzieży ze spektrum autyzmu. Wyniki badań pilotażowych
}

\begin{abstract}
Aneta Wojciechowska, Anna Gulczyńska, Zachowania seksualne dzieci $i$ mtodzieży ze spektrum autyzmu. Wyniki badań pilotażowych [Sexual behaviour of children and teenagers with autism spectrum disorders. Pilot study results]. Interdyscyplinarne Konteksty Pedagogiki Specjalnej, nr 19, Poznań 2017. Pp. 95-114. Adam Mickiewicz University Press. ISSN 2300-391X

In the article the results of pilot studies concerning manifestation of mother's sexuality in a group of children and youth with autism spectrum were presented. The research is divided into two fundamental parts. In the first part- the shortest one, definitions and conceptions were outlined. The subject of sexuality and functioning of people with autism spectrum disorders regarding social behaviors was also discussed. In the second part, the findings of own studies conducted on a group of mothers of children and youth with autism spectrum disorder were presented.
\end{abstract}

KEY WORDS: autism, children, sexual behaviors, youth

\section{Podłoże teoretyczne}

1. Zachowania seksualne człowieka nie są wyizolowanym obszarem życia, który można oddzielić od innych aktywności. Stanowią one integralny składnik osobowości, również tej rozwijającej się i manifestującej w sposób nienormatywny, nietypowy. Tym bar- 
dziej w funkcjonowaniu osób z określonymi zaburzeniami niemożliwe wydaje się oddzielenie sfery seksualnej od innych obszarów życia. Wpływa ona na owe obszary, a one zwrotnie wpływają na seksualność. „Człowiek rodzi się wyposażony w seksualny potencjał fizjologiczny, który ulega kształtowaniu przez doświadczenia życiowe; seksualność uwarunkowana jest zintegrowanym oddziaływaniem czynników biologicznych, psychicznych i społecznokulturowych" ${ }^{1}$. Płciowość jest trwałym atrybutem człowieka, ciągle dynamicznym - zmieniającym się zarówno w sferze biologicznej (fizjologicznej), jak i psychospołecznej, a co więcej - również w transakcjach zachodzących między tymi płaszczyznami. Powyższe założenia leżą u podłoża ekologicznego modelu seksualności Whalena i Schmidta, traktujących apetencję seksualną jako dyspozycję powstałą na podłożu właściwości wrodzonych, która rozwija się pod wpływem właściwości nabytych. W pierwszej płaszczyźnie znajduje się biofizjologia - $\mathrm{z}$ odpowiednim programem genetycznym, prawidłowym rozwojem organizmu, w tym ośrodków korowych, podkorowych, nerwów obwodowych, receptorów i hormonów, w drugiej mieszczą się właściwości nabyte - powstałe na trakcie uczenia się i doświadczania, związanych głównie z czynnikami wychowawczymi oraz kulturowymi².

Odnosząc powyższe założenia do osób z zaburzeniem ze spektrum autyzmu, powstałe $u$ nich dysfunkcje są niespecyficzne, trudno zatem jednoznacznie wskazywać konkretne uszkodzenia ośrodków korowych czy nerwów obwodowych związanych z zachowaniami seksualnymi. Aktualny stan wiedzy pozwala domniemywać, że biologiczne (fizjologiczne) podłoże zachowań seksualnych jest takie

${ }^{1}$ K. Imieliński, Zarys seksuologii i seksiatrii, Państwowy Zakład Wydawnictw Lekarskich, Warszawa 1986, s. 28.

2 Ibidem; A. Gulczyńska, Rodzinne uwarunkowania aktywności seksualnej młodych dorostych, Wydawnictwo Naukowe UAM, Poznań 2009; Jankowiak B., Aktywność seksualna nauczycieli a jakość $i$ trwatość ich związków partnerskich, Wydawnictwo Naukowe UAM, Poznań 2010; Steinberg L., Monahan K.C., Adolescents' Exposure to Sexy Media Does Not Hasten the Initiation of Sexual Intercourse, "Developmental Psychology" 2010, Vol. 47, No. 2, s. 562-576. 
samo, jak u osób bez zaburzeń rozwojowych. Powstające różnice w funkcjonowaniu seksualnym wynikają raczej z ograniczeń w umiejętnościach nawiązywania, utrzymywania i rozwijania relacji interpersonalnych, w szczególności z deficytów w obszarze teorii umysłu³.

2. U osób z zaburzeniem ze spektrum autyzmu sfera funkcjonowania społecznego jest, obok zaburzeń komunikacji i aktywności, obszarem, w którym obserwuje się duże deficyty. Dotyczą one umiejętności nawiązywania kontaktów z ludźmi, rozumienia społecznego, rozpoznawania i rozumienia emocji, a także zaburzeń w teorii umysłu - podstawy prawidłowego egzystowania wśród ludzi. Obszar funkcjonowania społecznego w klasyfikacji DSM-5 został połączony z możliwościami komunikacyjnymi osób ze spektrum autyzmu i nazwany zaburzeniami komunikacji społecznej (DSM- 5). Ujęcie to pokazuje, jak istotny jest obszar komunikacji w kontekście społecznym i takie podejście trafniej charakteryzuje problem, który ma znaczenie w kontekście podejmowanych rozważań o seksualności dzieci i młodzieży z autyzmem.

Analizując kryteria diagnostyczne (zob. ICD-10, DSM-5) ${ }^{4}$ oraz literaturę przedmiotu ${ }^{5}$, zauważyć można, że największą trudnością w okresie szkolnym u dzieci i młodzieży z zaburzeniem ze spek-

${ }^{3}$ Pojęcie teorii umysłu (pokrewne pojęcia: menatlizowanie - mentalizing, czytanie $\mathrm{w}$ umyśle - mindreading) dotyczy systemu pojęć i reguł, który pozwala ludziom przewidywać i wyjaśniać zachowania innych osób poprzez odnoszenie się do nieobserwowalnych stanów umysłu tj. pragnień, przekonań, intencji itp. Jest to zdolność do interpretowania działań własnych i innych jako kierowanych przez stany umysłu.

${ }^{4}$ Kryteria diagnostyczne wedtug DSM-IV-TR. 2008, redakcja wydania polskiego Jacek Wciórka, Wydawnictwo Elsevier, Diagnostic and statistical manual of mental disorders, Fifth edition, DSM-5, 2013, American Psychiatric Association.

${ }^{5}$ U. Frith, Autyzm. Wyjaśnienie tajemnic, Gdańskie Wydawnictwo Psychologiczne, Gdańsk 2008; J. Maljaars, I. Noens, R. Jansen, E. Scholte, I. van Berckelaer-Onnes, Intentional communication in nonverbal and verbal low-functioning children with autism, "Journal of Communication Disorders" 2011, Vol. 44, Issue 6, s. 601-614; E. Pisula, Autyzm. Od badań mózgu do praktyki psychologicznej, Sopot 2012; B. Winczura, Dziecko $z$ autyzmem, Terapia deficytów poznawczych a teoria umystu, Oficyna Wydawnicza „Impuls”, Kraków 2008. 
trum autyzmu jest podejmowanie interakcji, utrzymywanie kontaktu z drugą osobą i budowanie relacji opartych na obopólnych korzyściach i wymianie. Podstawę tych zachowań stanowi prawidłowy rozwój teorii umysłu. Zdolność do rozumienia, że człowiek ma uczucia, myśli i przekonania, że mogą one nie być dokładnym i realnym odzwierciedleniem rzeczywistości, jest ważnym aspektem społecznego rozumienia, nazywanym teorią umysłu (umiejętnością czytania w umyśle bądź umiejętnością metalizowania6 ${ }^{6}$. Umiejętność ta pozwalana na odnoszenie się do stanów psychicznych innych ludzi i przewidywania ich zachowań7. Autorzy podkreślają także, że ocena tej sfery wiąże się z możliwościami werbalnymi osoby, a wiedza na temat rozwoju tej umiejętności u dzieci niemówiących oraz osób z autyzmem z niepełnosprawnością intelektualną, jest niewielka ${ }^{8}$.

Badacze zauważają także, że osoby z zaburzeniem ze spektrum autyzmu z wczesnym prawidłowym rozwojem i późniejszym regresem wykształconych umiejętności, w przeciwieństwie do dzieci, u których objawy autyzmu pojawiły się już w pierwszym roku życia, wykazują lepsze umiejętności we wczesnym rozwoju teorii umysłu9.

Aspekt ten ma również znaczenie dla zachowań seksualnych dzieci i młodzieży z zaburzeniem ze spektrum autyzmu. Wskazuje on bowiem, że możliwość percepcji społecznej rzeczywistości związana jest nie tylko z możliwościami intelektualnymi, ale także z możliwościami językowymi osoby, co w znacznym stopniu po-

${ }^{6}$ S. Baron-Cohen, Mindblindness: An essay on autism and theory of mind. Dept of Experimental Psychology, The MIT Press, Cambridge 1995; F. Castelli, C. Frith, F. Happe, U. Frith, Autism, Asperger syndrome and brain mechanisms for the attribution of mental states to animated shapes, "Brain" 2002, Vol. 125(8), s. 1839-1849.

7 L. Colle, S. Baron-Cohen, J. Hill, Do Children with Autism have a Theory of Mind? A Non-verbal. Test of Autism vs. Specific Language Impairment, "Journal of Autism and Developmental Disorders" 2007, nr 37, s. 716-723.

8 Ibidem.

${ }_{9}^{9}$ N.L. Matthews, W.A. Goldberg, A.F. Lukowski, K. Osann, M.M. Abdullah, A.R. Ly, K. Thorsen, M.A. Spence, Does theory of mind performance differ in children with early-onset and regressive autism?, "Developmental Science” 2012, nr 15, 1, s. 25-34. 
winno determinować (szeroko rozumiane) kształcenie w tej sferze dzieci i młodzieży z omawianym problemem rozwojowym.

Podsumowując, osoba ze spektrum autyzmu w okresie dorastania podlega takim samym przemianom biologicznym jak nastolatek w jego wieku bez zaburzeń w rozwoju, jednak postrzeganie własnej osoby i droga do akceptacji zmian, jakie zachodzą $w$ jego organizmie, zależne są od wielu czynników zarówno zewnętrznych, jak i możliwości poznawczych i umiejętności społeczno-emocjonalnych ${ }^{10}$. To poprzez identyfikację $\mathrm{z}$ grupą społeczną $\mathrm{i}$ wchodzenie w nowe role młody człowiek zaczyna postrzegać siebie jako kogoś równego innym bądź odbiegającego od najbliższego otoczenia. Uczeń z zaburzeniem ze spektrum autyzmu, funkcjonujący na poziomie normy intelektualnej, często zauważa swoją odmienność od rówieśników i im jest starszy dostrzega swoje trudności w budowaniu relacji rówieśniczych ${ }^{11}$.

\section{Metoda badawcza i charakterystyka próby badawczej}

W badaniu wykorzystano autorski kwestionariusz ankiety skonstruowany na podstawie analizy literatury ${ }^{12}$ oraz obserwacji dzieci

10 A. Wojciechowska, Pomiędzy dzieciństwem a dorosłościa - o dorastaniu osób z zespotem Aspergera, „Studia Edukacyjne” 2013a, nr 25, s. 137-148.

11 T. Atwood, Zespót Aspergera. Kompletny przewodnik, Harmonia Universalis, Gdańsk 2013; A. Wojciechowska, Wśród ludzi na własnych zasadach? O możliwościach i ograniczeniach w budowaniu relacji z rówieśnikami przez młodzież z zespołem Aspergera, „Studia Edukacyjne" 2013b nr 28, s. 227-242.

12 W tym: T. Atwood, op. cit.; R. Aylaz, U. Yilmaz, S. Polat, Effect of Difficulties Experienced by Parents of Autistic Children on Their Sexual Life: A Qualitative Study, "Sexuality and Disability" 2016, nr 30, s. 395-406; M.S. Ballan, Parental Perspectives of Communication about Sexuality in Families of Children with Autism Spectrum Disorders, "Journal of Autism and Developmental Disorders" 2012, nr 42, s. 676-684; H. Hellemans, K. Colson, C. Verbraeken, R. Vermeiren, D. Deboutte, Sexual behavior in highfunctioning male adolescents and young adults with autism spectrum disorders, "Journalof Autism and Developmental Disorders" 2007, nr 37, s. 260-269; M.L. Bellon-Harn, W.E. Harn, Profiles of social communicative competence in middle school children with 
i młodzieży z zaburzeniem spektrum autyzmu. Ponieważ niniejsze badania są pilotażowe, poproszono również badane matki o uwagi i komentarze, które będą uwzględnione przy tworzeniu wersji ostatecznej narzędzia.

Z założenia docelową próbą badawczą byli rodzice dzieci i młodzieży z zaburzeniami ze spektrum autyzmu, jednak ankietę wypełniły jedynie matki. Prawdopodobnie wynika to $z$ faktu, że to one dysponują największym zasobem wiedzy dotyczącym informacji koniecznych do wypełnienia kwestionariusza ankiety oraz spędzają najwięcej czasu ze swoim dzieckiem.

W badaniu wzięło udział 18 matek dzieci z klas IV-VI szkoły podstawowej oraz $20 \mathrm{z}$ gimnazjum. Ankiety wypełniane były anonimowo - $w$ formie papierowej lub poprzez stronę internetową. $Z$ uwagi na deklarowany przez rodziców dyskomfort związany $\mathrm{z}$ tematem badania, do niniejszych badań pilotażowych pozyskano łącznie 38 ankiet.

Osobami wypełniającymi ankiety dotyczące uczniów uczęszczających do szkoły podstawowej były matki - w większości chłopców (69 \%), najstarsza respondentka miała 55 lat, najmłodsza 34, pochodzące w większości ze średniego miasta (do 200 tys. mieszkańców). Większość matek opisuje siebie jako osoby wierzące i nieregularnie praktykujące.

Osobami wypełniającymi ankiety dotyczące uczniów uczęszczających do gimnazjum były matki chłopców, najstarsza respondentka miała 51 lat, najmłodsza 38, pochodzące w większości z dużego miasta (powyżej 200 tys. mieszkańców). Z wyjątkiem osób uważających siebie za niezadeklarowane religijnie, których jest najmniej, pozostały rozkład wyników był dla kategorii: niewierzący, wierzący i niepraktykujący, wierzący i nieregularnie praktykujący, wierzący i regularnie praktykujący taki sam (po 20\%).

Asperger syndrome: Two case studies, "Child Language Teaching and Therapy" 2006, nr 22, 1, s. 1-26; F. Castelli, Understanding emotions from standardized facial expressions in autism and normal development, "Autistic Society" 2005, nr 9, 4, s. 428-449; M. Zielona-Jenek, A. Chodecka, Jestem dziewczynka, jestem chtopcem. Jak wspomagać rozwój seksualny dziecka, Gdańskie Wydawnictwo Psychologiczne, Gdańsk 2010. 
Zdecydowano się przedstawić wyniki procentowo, co ma na celu ukazanie, jak często $\mathrm{w}$ badanej próbie opinia lub zachowanie występowało. Autorki akcentują, że zastosowanie wyników procentowych na tak małej próbie badawczej ma wskazywać jedynie pewną tendencję, której kierunek będzie weryfikowany w dalszych badaniach. Nie upoważnia to jednak do generalizowania uzyskanych wyników na populację.

\section{Problemy badawcze}

Celem prezentowanych wyników badania pilotażowego jest przedstawienie opinii matek na temat zachowań seksualnych dzieci (szkoła podstawowa klasy IV-VI) i młodzieży (gimnazjum) z zaburzeniem ze spektrum autyzmu. Zbadano zarówno ich rodzaj, jak i częstotliwość występowania.

Postawiono następujące problemy badawcze:

1. Z jakich źródeł matki dzieci i młodzieży z zaburzeniem spektrum autyzmu czerpią wiedzę na temat rozwoju seksualnego swoich dzieci?

2. Z jakich źródeł dzieci i młodzież z zaburzeniem spektrum autyzmu czerpie wiedzę na temat własnego rozwoju seksualnego?

3. Czy i jakie różnice, zdaniem matek dzieci i młodzieży ze spektrum autyzmu, występują $\mathrm{w}$ rozwoju seksualnym ich dzieci w porównaniu z dziećmi i młodzieżą bez spektrum autyzmu?

4. Jakie oznaki dojrzewania płciowego u dzieci i młodzieży ze spektrum autyzmu obserwowane są przez matki oraz jaka jest ich częstotliwość?

\section{Wyniki badań pilotażowych}

1. Szkoła podstawowa

Opisywane przez matki zachowania dotyczyły większości chłopców z zaburzeniami ze spektrum autyzmu. Prawie połowa 
dzieci jest w normie intelektualnej, a druga połowa ma zdiagnozowaną niepełnosprawność intelektualną. Większość dzieci mówi, tylko nieliczne używają komunikacji alternatywnej. Dzieci uczą się w szkołach specjalnych, w szkołach masowych lub w klasach integracyjnych. Zajęcia $z$ edukacji seksualnej obywają się $\mathrm{w}$ prawie połowie szkół, nie odbywają również w prawie połowie szkół, a kilkoro respondentek nie posiada wiedzy na ten temat. Większość dzieci nie uczestniczy w takich zajęciach. Ponad połowa matek twierdzi, że nikt nie pytał ich o zgodę na uczestniczenie dziecka w zajęciach z wychowania do życia w rodzinie (edukacji seksualnej).

W postawionym pytaniu, skąd czerpią wiedzę na temat rozwoju seksualnego swoich dzieci, matki mogły udzielić więcej niż jednej odpowiedzi (tabela 1).

Na pierwszym miejscu znajduje się literatura, dalej: internet, inni rodzice, terapeuci nauczyciele oraz inne (w tym wykład prowadzony przez specjalistę).

Tabela 1. Źródła, z których matki czerpią wiedzę na temat rozwoju seksualnego swoich dzieci uczęszczających do szkół podstawowych

\begin{tabular}{|l|c|}
\hline \multicolumn{1}{|c|}{ Źródła } & Procent \\
\hline Literatura naukowa i popularno-naukowa & 81 \\
\hline Internet & 62 \\
\hline Inni rodzice & 50 \\
\hline Terapeuci & 42 \\
\hline Nauczyciele & 29 \\
\hline Inne & 10 \\
\hline
\end{tabular}

Źródło: badania własne

Zdaniem matek, ich dzieci czerpią wiedzę dotyczącą rozwoju seksualnego z internetu (ponad 80\%), z telewizji (ponad 50\%), od terapeutów i z literatury (po 18\%), a także z innych źródeł, jak np. rodzice. 
W dalszej kolejności zapytano, co zdaniem matek różni rozwój seksualny dzieci bez zaburzeń ze spektrum autyzm od rozwoju seksualnego dzieci z tym zaburzeniem. Udzielone odpowiedzi zaszeregowano w sześć kategorii: nie widzę różnic, brak świadomości związanej ze zmianami, jakie się dzieją w organizmie oraz brak wyczucia, jakie zachowania są akceptowane społecznie (powyższe odpowiedzi sumowały się w 90\%, przy podobnym rozkładzie między grupami), kolejnymi kategoriami odpowiedzi były: nie zauważyłam jeszcze oznak seksualności dziecka oraz: dzieci ze spektrum są bardziej wrażliwe w tym temacie, bardziej wyczulone na swoją seksualność, a także: nie wiem (odpowiedzi te sumowały się w 10\%).

W dalszej kolejności pytano, jak często dane zachowanie występuje u dziecka (matki mogły udzielić odpowiedzi na skali od: 0 - nie występuje do 4 - występuje ciągle).

$\mathrm{Na}$ pytanie dotyczące obserwowalnych przejawów oznak dojrzewania płciowego u swoich dzieci 20\% respondentek odpowiedziało, że ich nie zauważa, dla 30\% oznaki takie są wciąż obecne lub bardzo często $(20 \%)$, pozostałe $30 \%$ widzi je rzadko lub czasami. Korespondują z tym odpowiedni na pytanie, czy matki obserwują zwiększone zapotrzebowanie na prywatność u swoich dzieci. Prawie $20 \%$ uważa, że nie, w $45 \%$ dostrzega potrzebę rzadko, pozostałe respondentki - bardzo często lub ciągle. Większość matek (ponad 70\%) stwierdza jednak, że nie obserwują u swoich dzieci zakłopotania ani zwiększonej wstydliwości związanej z kwestią seksualności i zmianami w budowie ciała, 20\% dostrzega zachowanie rzadko, a niespełna $10 \%$ wciąż. Podobny odsetek (ponad 70\%) nie obserwuje u swoich dzieci lęku o własną normalność, 20\% rzadko dostrzega jego przejawy, a 10\% często.

Ponad 50\% matek nie było pytanych przez dzieci o kwestie związane z seksualnością, prawie 30\% rzadko, 20\% często i bardzo często. Zainteresowania płcią przeciwną nie obserwuje ponad $60 \%$ badanych, a około $40 \%$ dostrzega takie przejawy rzadko. 60\% matek zauważa zainteresowanie tematem skąd się biorą dzieci, w tym $30 \%$ rzadko, 30\% często i bardzo często. Koresponduje to w obserwowanym przez matki zainteresowaniu różnicami w budowie 
fizycznej chłopców, dziewcząt: w 35\% rzadko, w 30\% często i bardzo często.

Dla większości badanych matek najtrudniejszymi są zachowania ich dzieci związane $\mathrm{z}$ publicznym rozbieraniem, przytulaniem i całowaniem innych osób (po 30\%), następnie masturbacja, potem: poszukiwanie treści pornograficznych $\mathrm{w}$ internecie oraz głośne wypowiadaniem treści o charakterze seksualnym (prawie 20\% każda $\mathrm{z}$ wypowiedzi).

Wszystkie respondentki nie obserwują u swoich dzieci z klas IV-VI całowania (lub takich prób) zarówno rówieśników - tej samej płci, jak i płci odmiennej. Jednocześnie ponad $80 \%$ matek nie zauważyło zachowań ekshibicjonistycznych. Podobny procent respondentek nie zauważył przejawów masturbacji u swoich dzieci. Ponad $60 \%$ matek uważa, że ich dzieci nie dotykają swoich miejsc intymnych w obecności innych, 30\% twierdzi, że dane zachowanie występuje rzadko, a prawie $10 \%$, że często. Kiedy dochodzi komponent emocjonalny - lęku, czy ekscytacji, wyniki ulegają zmianie jedynie w rozkładzie rzadko (u $20 \%$ występuje takie zachowanie) i często (20\%). 90\% respondentek podaje, że nie zważyły, aby ich dzieci poszukiwały treści seksualnych $\mathrm{w}$ internecie lub telewizji ani prezentowały intymnych części ciała innym dzieciom.

Do rzadkości należy też włączanie w zabawy elementów zachowań seksualnych (w $80 \%$ brak takich zachowań, w 20\% występuje rzadko). Podobnie uczestnictwo $w$ zabawach uznanych za właściwe dla płci przeciwnej (ponad 70\% nie występuje, w około $20 \%$ pojawia się rzadko, często tylko u $10 \%$ ). W większości matki (ponad 70\%) nie zaobserwowały również negatywnego wypowiadania się o dzieciach płci przeciwnej (np. dziewczyny są głupie albo: chłopcy są tępi i hałaśliwi), takie zachowania rzadko obserwuje $10 \%$ respondentek, a często prawie $20 \%$. Podglądanie dzieci, gdy są w łazience, w przypadku większości $(90 \%)$ podopiecznych nie jest obserwowane, a $10 \%$ robi to wciąż. $Z$ kolei próby wchodzenia do toalety $z$ innymi raczej nie występują $(60 \%)$, występują rzadko (20\%), często lub bardzo często w przypadku $10 \%$. 
$45 \%$ dzieci nie zabiega o przytulanie ani nie przytula innych dzieci, natomiast większość dzieci domaga się przytulania przez dorosłych (40\% bardzo często i często, 50\% rzadko), jednak zdecydowana większość (ponad 70\%) nie podejmuje prób całowania dorosłych kobiet w szkole, fundacji, poradni, a sporadyczne zachowania pojawiają się rzadko. Ponad połowa respondentek obserwuje z kolei naśladowanie tańca nastolatków (w tym ponad 30\% rzadko, a po $10 \%$ często i bardzo często).

\section{Gimnazjum}

Opisywane zachowania dotyczyły tylko chłopców, najstarszy ma 18 lat, najmłodszy 14 lat. Większość dzieci respondentek jest w normie intelektualnej. Wszyscy podopieczni komunikują się werbalnie. Adolescenci uczą się w szkołach specjalnych, masowych lub w klasach integracyjnych. Zajęcia z edukacji seksualnej obywały się w ponad połowie szkól, a tylko kilkoro respondentek nie posiada wiedzy na ten temat. Ponad połowa nastolatków uczestniczy w takich zajęciach. Prawie połowa respondentek twierdzi, że była pytana o zgodę na uczestniczenie dziecka w zajęciach $\mathrm{z}$ wychowania do życia w rodzinie (edukacji seksualnej), taka sama liczba deklaruje, że nie była pytana.

Na postawione pytanie, skąd czerpią wiedzę na temat rozwoju seksualnego swoich dzieci, matki mogły udzielić więcej niż jednej odpowiedzi (tabela 2). W kolejności wymieniły: literaturę (naukową, popularnonaukową), innych rodziców, internet, terapeutów, rozmowę z dzieckiem, telewizję, nauczycieli, własne studia i szkolenie.

Zdaniem matek, ich dzieci z kolei czerpią wiedzę dotyczącą rozwoju seksualnego z internetu (prawie 80\%), od rówieśników (ponad 60\%) oraz telewizji (ponad 50\%) i terapeutów (ponad 20\%).

W dalszej kolejności zapytano, co zdaniem matek różni rozwój seksualny dzieci bez zaburzenia ze spektrum autyzm od rozwoju seksualnego dzieci z tym zaburzeniem?

Udzielone odpowiedzi zaszeregowano w pięć kategorii: brak równoległości między dojrzewaniem fizycznym a emocjonalnym 
Tabela 2. Źródła, z których matki czerpią wiedzę na temat rozwoju seksualnego swoich dzieci uczęszczających do gimnazjum

\begin{tabular}{|l|c|}
\hline \multicolumn{1}{|c|}{ Źródła } & Procent \\
\hline Literatura naukowa i popularno-naukowa & 65 \\
\hline Inni rodzice & 62 \\
\hline Internet & 57 \\
\hline Terapeuci & 55 \\
\hline Rozmowa z dzieckiem & 29 \\
\hline Telewizja & 10 \\
\hline Nauczyciele & 10 \\
\hline Własne studia i szkolenie & 10 \\
\hline
\end{tabular}

Źródło: badania własne

(opóźniony rozwój emocjonalny) 50\%, nie widzę różnic - 20\%, nie wiem - $10 \%$, zbytnia otwartość i szczerość dzieci (10\%) oraz trudności w komunikacji (10\%).

W dalszej kolejności pytano, jak często dane zachowanie występuje u nastolatka (rodzice mogli udzielić odpowiedzi na skali od: 0 - nie występuje do 4 - występuje ciągle). Sformułowane tak pytania mają oddawać subiektywne obserwacje i odczucia matek.

Przejawy dojrzewania płciowego $u$ swoich nastoletnich dzieci obserwują wszystkie respondentki z czego dla większości są one wciąż obecne $(60 \%)$, bardzo często lub często (ponad 30\%). Korespondują z tym wyniki uzyskane z pytania, czy matki notują zwiększone zapotrzebowanie na prywatność u swoich dzieci. Obserwacje takie mają wszystkie respondentki, w tym prawie $90 \%$ uważa, że zachowania o tym świadczące są bardzo częste i częste, a 10\% dostrzega taką potrzebę rzadko. Ponad połowa matek (55\%) wie, że ich dzieci masturbują się rzadko (45\%) lub wciąż (10\%), 45\% nie obserwuje u swoich synów autoerotyki. Ponad połowa matek (55\%) stwierdza jednak, że nie widzi u swoich dzieci zakłopotania ani zwiększonej wstydliwości związanej z kwestią seksualności i zmianami w budowie ciała, ponad 30\% dostrzega zachowanie rzadko, 
a niespełna $10 \%$ często. Ponad połowa matek obserwuje u swoich dzieci lęk o własną normalność (w tym ponad 20\% rzadko, ponad 30\% często, bardzo często i wciąż).

Ponad 50\% matek było pytanych przez dzieci o kwestie związane $\mathrm{z}$ seksualnością. Zainteresowania płcią przeciwną nie obserwuje jedynie $20 \%$ respondentek, pojawiają się one często lub bardzo często u ponad $40 \%$ adolescentów, ponad $30 \%$ - rzadko. Koresponduje to $\mathrm{z}$ obserwowanym przez matki zainteresowaniem różnicami w budowie fizycznej chłopców i dziewcząt: $20 \%$ młodzian nie interesuje się tym wcale, ponad $50 \%$ przejawia takie zainteresowanie incydentalnie, 30\% często i wciąż.

Dla większości badanych matek najtrudniejszymi są zachowania ich dzieci związane z masturbacją (55\%), głośnym wypowiadaniem treści o charakterze seksualnym (ponad połowa), publicznym rozbieraniem (ponad 30\%), przytulaniem i całowaniem innych osób (ponad $20 \%$ ), następnie poszukiwaniem treści pornograficznych w internecie.

Matki nie zauważają u swoich dorastających synów następujących zachowań: wchodzenia (lub prób wchodzenia) do toalety z innymi, całowania (lub prób całowania) rówieśników tej samej lub innej płci publicznie, jak również osób pracujących w ośrodkach (szkołach, poradniach), a także prezentowania intymnych części ciała. Akty ekshibicjonizmu zakończone ucieczką należą również do rzadkości. Podglądanie innych, gdy są w łazience, w przypadku większości (80\%) nie jest obserwowane, a pozostali robią to rzadko.

Ponad 40\% matek uważa, że ich dzieci nie dotykają swoich miejsc intymnych $\mathrm{w}$ obecności innych, 30\% twierdzi, że dane zachowanie występuje rzadko, 20\% uważa, że często lub wciąż. Kiedy dochodzi komponent emocjonalny - lęku czy ekscytacji, nie ma to wpływu dla 30\% opisywanych, dzieje się tak często i bardzo często u ponad $40 \%$ nastolatków, rzadko u ponad $20 \%$.

Poszukiwanie seksualnych treści w internecie zauważa u swoich dzieci 55\% matek (w tym ponad 30\% rzadko, a 20\% często), natomiast telewizji $45 \%$ (w tym ponad 30\% rzadko, a 10\% często).

Do rzadkości należy też włączanie w aktywność wątku zachowań seksualnych (w 80\% brak takich zachowań, w 20\% występuje 
rzadko). Ponad połowa matek nie słyszała, aby ich synowie wypowiadali się negatywnie o dziewczętach.

$90 \%$ chłopców nie zabiega ani nie przytula dorosłych w swoim wieku lub robi to rzadko (po 45\%), również przytulanie rówieśników ma miejsce sporadycznie (45\%) lub wcale (55\%). 45\% dzieci respondentek nie miało doświadczeń z posiadaniem pierwszego chłopaka, czy dziewczyny, $45 \%$ miało takie spotkania rzadko, a jedynie ponad $10 \%$ często. Połowa respondentek (55\%) nie obserwuje naśladowania tańca nastolatków, a połowa ma obserwacje często.

\section{Wnioski}

Koncepcję badań opracowano w oparciu o dostępną literaturę przedmiotu, obserwację (w tym obserwację uczestniczącą) dzieci z klas IV-VI oraz gimnazjalnych i rozmowy z rodzicami. Dzięki zaangażowaniu matek wypełniających kwestionariusze ankiety można było rozszerzyć badania o pewne kategorie odpowiedzi, które wcześniej nie zostały uwzględnione.

Szkoła podstawowa: większość matek biorących udział w badaniu zaobserwowała u swoich dzieci objawy dojrzewania płciowego, jednak nie są one bardzo widoczne. Zwiększone zapotrzebowanie na prywatność pojawia się rzadko. Rzadko też dzieci manifestują zakłopotanie albo wstydliwość związaną z kwestią seksualności czy zmianami w budowie ciała. Podobnie nie przejawiają lęku o własną normalność.

Matki swoją wiedzę o seksualności uzupełniały odpowiednio: czytając dostępną literaturę i odwiedzając strony internetowe, rozmawiając z innymi rodzicami, dalej: od terapeutów i nauczycieli. Ich zdaniem dzieci dowiadują się o kwestiach związanych z seksualnością głównie z Internetu i telewizji, w dalszej kolejności terapeutów i nauczycieli. Same natomiast, w ponad połowie, nie były pytane przez swoje dzieci o kwestie związane z seksualnością.

W większości respondentki twierdzą, że rozwój seksualności $\mathrm{u}$ ich dzieci z zaburzeniem ze spektrum autyzmu przebiega inaczej 
niż u osób bez takiej diagnozy. Główna różnica według nich polega na braku świadomości zmian zachodzących w organizmie oraz rodzaju społecznie akceptowanych zachowań.

Za najtrudniejsze przejawiane w tym okresie zachowania uważają publiczne rozbieranie się, przytulanie i całowanie innych osób.

Gimnazjum: wszystkie matki biorące udział w badaniu zaobserwowały $u$ swoich synów objawy dojrzewania płciowego oraz zwiększone zapotrzebowanie na prywatność. Swoją wiedzę w tym zakresie uzupełniały odpowiednio: czytając dostępną literaturę, rozmawiając $\mathrm{z}$ innymi rodzicami, szukając na stronach internetowych, od terapeutów, poprzez rozmowę z dzieckiem, oglądanie telewizji, od nauczycieli czy też własne studia i szkolenia.

Ich zdaniem dorastający synowie dowiadują się o kwestiach związanych z seksualnością głównie z internetu i od rówieśników, w dalszej kolejności z telewizji i od terapeutów; kolejno od nauczycieli, innych rodziców. Literatura jako źródło wiedzy o seksualności plasuje się na ostatnim miejscu. W większości respondentki twierdzą, że rozwój seksualności adolescentów z zaburzeniami ze spektrum autyzmu przebiega inaczej niż u osób bez takiej diagnozy; główna różnica polega na opóźnionym rozwoju emocjonalnym oraz obserwowanej u synów koncentracji na fizjologicznych komponentach dojrzewania. Za najtrudniejsze przejawiane $w$ tym okresie zachowania uważają masturbację, głośne wypowiadanie treści o charakterze seksualnym, w dalszej kolejności publiczne rozbieranie, poszukiwanie treści pornograficznych w internecie czy całowanie innych osób. Zwracają również uwagę na rzadką lub prawie nieobserwowaną wstydliwość $u$ tych młodych mężczyzn związaną z kwestiami seksualnymi i faktem dojrzewania płciowego. Ponad połowa matek została zaproszona do rozmowy lub zapytana przez swoje dzieci o tematy seksualne. Co ważne, u ponad połowy matki dostrzegają lęk o własną normalność i dylematy w tym zakresie. Pierwsze doświadczenia $\mathrm{z}$ randkowaniem ma za sobą ponad połowa synów respondentek, jednak ich jakość i trwałość nie była przedmiotem niniejszych badań. Charakteryzując zachowania seksualne swoich dojrzewających synów, matki opisują zwiększenie 
masturbacji oraz duże zainteresowanie budową narządów płciowych i różnicami w tym zakresie u kobiet (dziewcząt) i mężczyzn (chłopców), a także ciekawość skąd się biorą dzieci. Innymi obserwowanymi zachowaniami o zabarwieniu seksualnym są: naśladowanie tańca nastolatków, dotykanie intymnych części ciała w obecności innych osób oraz dotykanie własnych narządów płciowych w momencie ekscytacji czy lęku, zabieganie o bycie przytulonym czy też poszukiwanie treści o charakterze seksualnym $\mathrm{w}$ internecie lub telewizji.

\section{Dyskusja}

Analiza materiału zebranego w badaniach pilotażowych, których celem było poznanie opinii matek na temat zachowań seksualnych dzieci i młodzieży z zaburzeniem ze spektrum autyzmu, wskazała istotność danego problemu oraz potrzebę kontynuacji badań naukowych $\mathrm{w}$ tym zakresie. Wyłoniły się prawdopodobne trudności, z jakimi borykają się matki osób z zaburzeniem ze spektrum autyzmu, a także wskazano, że temat ten budzi u nich lęk.

Odpowiedzi matek uczniów szkół podstawowych na część pytań pozostają w pozornej sprzeczności wobec siebie. Mianowicie matki uważają, że dzieci czerpią wiedzę dotyczącą rozwoju seksualnego głównie z internetu oraz telewizji, jednocześnie uważają, że ich dzieci nie poszukują treści seksualnych w internecie. Uzyskane wyniki stają się źródłem hipotez do dalszych badań, a mianowicie: prawdopodobnym jest, że matki odniosły się do dzieci jako kategorii ogólnej, poszukujących treści o rozwoju seksualnym $\mathrm{w}$ internecie (w pytaniu nie było odniesienia do ich własnych dzieci) lub uważają, że dzieci stają się jedynie mimowolnym odbiorcą treści seksualnych.

Oznaki dojrzewania były obserwowane rzadko i adekwatnie do tego - matki obserwowały zapotrzebowanie na intymność. W przypadku młodzieży gimnazjalnej oznaki dojrzewania płciowego występują u wszystkich, natomiast zakłopotanie czy wstydliwość zwią- 
zana z kwestią seksualności i zmianami w obszarze ciała - rzadko, będąc na poziomie zbliżonym do dzieci z klas IV-VI.

Dokonując analizy literatury przedmiotu, zauważyć można, że treści dotyczące rozwoju seksualnego, zachowań seksualnych oraz edukacji seksualnej osób z zaburzeniami ze spektrum autyzmu są podejmowane $\mathrm{w}$ polskich publikacjach rzadko. W roku $2008 \mathrm{w}$ dostępnej przez system EBSCO bazie literatury zagranicznej, na temat seksualności osób ze spektrum autyzmu było tylko 20 pozycji ${ }^{13}$. We wrześniu 2014 r. wyszukiwarka wskazała 46 publikacji (autism, sexuality).

Dojrzewanie fizyczne $\mathrm{u}$ osób zaburzeniem ze spektrum autyzmu zazwyczaj przebiega normalnie, czego przejawem jest między innymi pojawianie się drugorzędowych cech płciowych, ale dojrzewanie emocjonalne i związane $\mathrm{z}$ tym seksualne, jest znacznie wydłużone, opóźnione ${ }^{14}$ lub przebiega charakterystycznie dla danej osoby, co potwierdziły także opinie uzyskane od matek w niniejszym pilotażu.

Osoby $\mathrm{w}$ normie intelektualnej $\mathrm{z}$ zaburzeniem spektrum autyzmu (w normie intelektualnej) mają pragnienie kontaktów społecznych i stosunków seksualnych; brak realizacji tych zachowań wynika $\mathrm{z}$ upośledzenia $\mathrm{w}$ zakresie odpowiedniego rozumienia i budowania relacji. Zachowania badanych piętnastolatków ze spektrum autyzmu odpowiadały zachowaniom dziesięciolatków bez takiego rozpoznania ${ }^{15}$, co obserwowane jest także przez polskie respondentki.

Różnicę zauważa się w podejściu do problemu seksualności rodziców osób z zaburzeniami ze spektrum autyzmu w Polsce, w porównaniu do wyników zagranicznych badań, które wykazały że seksualność autystycznych podopiecznych była wysoko na liście

13 A. Sullivan, L.C. Caterino, Addressing the Sexuality and Sex Education of Individuals with Autism Spectrum Disorders, "Education and Treatment of Children" 2008, vol. 31, No. 3, s. 381-394.

14 Ibidem.

15 M.A. Stokes, A. Kaur, High functioning autism and sexuality: A parental perspective, "Autism" 2005, nr 9(3), s. 266-289. 
głównych problemów, w których rodzice szukali pomocy i wsparcia $^{16}$. Może wynikać to $\mathrm{z}$ faktu, że temat seksualności $\mathrm{w}$ Polsce jest tematem tabu, a seksualność niepełnosprawnych tym bardziej jest zagadnieniem, o którym nie często się mówi, nawet $\mathrm{w}$ gronie specjalistów i badaniach naukowych.

Z kolei w innych badaniach ${ }^{17}$ wykazano brak wglądu w motywy swojego działania, ograniczone rozumienie i świadomość sytuacji społecznych, ograniczoną empatię, ponadto brak hamowania i wiedzy, a także troski, zmniejszone rozpoznawanie emocji oraz trwałe, powtarzające się i stereotypowe zachowania. Uzyskane $\mathrm{w}$ badaniach pilotażowych wyniki korespondują z powyższymi wnioskami.

Inne badania ${ }^{18}$ akcentują większą potrzebę wiedzy w zakresie zmieniającego się ciała i funkcji organizmu u osób z zespołem Aspergera. W niniejszych badaniach pilotażowych rodzice adolescentów podają, że kwestia fizjologii jest rozpoznawana przez ich synów, natomiast pogłębienia i zdobycia wyższych kompetencji upatrują w rozwoju emocjonalnym.

Niniejsze badania miały w zamierzeniu stać się przyczynkiem do bardziej pogłębionych analiz i eksploracji danej tematyki, a w przyszłości także do wyciagnięcia szerszych wniosków i przełożenia ich na grunt praktyki.

\section{Bibliografia}

Atwood T., Zespót Aspergera. Kompletny przewodnik, Harmonia Universalis, Gdańsk 2013.

${ }^{16}$ N. van Son-Schoones, P. van Bilsen, Sexuality and autism: a pilotstudy of parents, health care workers and autistic persons, "International Journal of Adolescent Medicine and Health" 1995, nr 8, s. 87-101.

${ }_{17}$ M. Stokes, N. Newton, A. Kaur, Stalking, and social and romantic functioning among adolescents and adults with autism spectrum disorder, "Journal of Autism and Developmental Disorders" 2007, nr 37, s. 1969-1986.

${ }^{18}$ I. Henault, Asperger's Syndrome and Sexuality: From Adolescence through Adulthood, Jessica Kingsley Birmingham, AL, USA EBSCO Industries, Inc., London 2006. 
Aylaz R., Yilmaz U., Polat, S., Effect of Difficulties Experienced by Parents of Autistic Children on Their Sexual Life: A Qualitative Study, "Sexuality and Disability" 2016, nr 30.

Ballan M.S., Parental Perspectives of Communication about Sexuality in Families of Children with Autism Spectrum Disorders, "Journal of Autism and Developmental Disorders" 2012, nr 42.

Baron-Cohen S., Mindblindness: An essay on autism and theory of mind. Dept of Experimental Psychology, US: The MIT Press, Cambridge 1995.

Bellon-Harn M.L., Harn W.E., Profiles of social communicative competence in middle school children with Asperger syndrome: Two case studies, "Child Language Teaching and Therapy" 2006, nr 22, 1.

Castelli F., Understanding emotions from standardized facial expressions in autism and normal development, "Autistic Society" 2005, nr 9, 4.

Castelli F., Frith C., Happe F. Frith U., Autism, Asperger syndrome and brain mechanisms for the attribution of mental states to animated shapes, "Brain" 2002, Vol. 125(8).

Colle L., Baron-Cohen S., Hill J., Do Children with Autism have a Theory of Mind? A Non-verbal. Test of Autism vs. Specific Language Impairment, "Journal of Autism and Developmental Disorders" 2007, nr 37.

Diagnostic and statistical manual of mental disorders. Fifth edition. DSM-5. 2013. American Psychiatric Association.

Frith U., Autism: Explaining the Enigma, Blackwell Pub, Cambridge 2003.

Frith U., Autyzm. Wyjaśnienie tajemnic, Gdańskie Wydawnictwo Psychologiczne, Gdańsk 2008.

Gulczyńska A., Rodzinne uwarunkowania aktywności seksualnej młodych dorosłych, Wydawnictwo Naukowe UAM, Poznań 2009.

Hellemans H., Colson K., Verbraeken C., Vermeiren R., Deboutte D., Sexual behavior in high-functioning male adolescents and young adults with autism spectrum disorders “Journalof Autism and Developmental Disorders" 2007, nr 37.

Henault I., Asperger's Syndrome and Sexuality: From Adolescence through Adulthood, London 2006.

Imieliński K., Zarys seksuologii i seksiatrii, Państwowy Zakład Wydawnictw Lekarskich, Warszawa 1986.

Jankowiak B., Aktywność seksualna nauczycieli a jakość i trwałość ich związków partnerskich, Wydawnictwo Naukowe UAM, Poznań 2010.

Kościelska M., Niechciana seksualność. O ludzkich potrzebach osób niepetnosprawnych intelektualnie, Wydawnictwo Jacek Santorski \& Co, Warszawa 2004.

Kryteria diagnostyczne wedtug DSM-IV-TR. 2008, Redakcja wydania polskiego Jacek Wciórka. Wydawnictwo Elsevier, 2008

Maljaars J., Noens I., Jansen R., Scholte E., van Berckelaer-Onnes I., Intentional communication in nonverbal and verbal low-functioning children with autism, "Journal of Communication Disorders" 2011, Vol. 44 Issue 6. 
Matthews N.L., Goldberg W.A., Lukowski A.F., Osann K., Abdullah M.M., Ly A.R., Thorsen K., Spence M.A., Does theory of mind performance differ in children with early-onset and regressive autism?, „Developmental Science” 2012, nr 15, 1.

Pisula E., Autyzm. Od badań mózgu do praktyki psychologicznej, Sopot 2012.

Sullivan A., Caterino L.C., Addressing the Sexuality and Sex Education of Individuals with Autism Spectrum Disorders, "Education and Treatment of Children" 2008, vol. 31, No. 3.

Rybakowski F., Białek A., Chojnicka I., Dziechciarz P., Horvath A., Janas-Kozik M., Jeziorek A., Pisula E., Piwowarczyk A., Słopień A., Sykut-Cegielska J., Szajewska H., Szczałuba K., Szymańska K., Urbanek K., Waligórska A., Wojciechowska A., Wroniszewski M., Dunajska A., Zaburzenia ze spektrum autyzmu - epidemiologia, objawy, wspótzachorowalność i rozpoznawanie, „Psychiatria Polska” 2014, nr 48 (4).

Steinberg L., Monahan K.C., Adolescents' Exposure to Sexy Media Does Not Hasten the Initiation of Sexual Intercourse ", Developmental Psychology" 2010, Vol. 47, No. 2.

Stokes M., Newton N., Kaur A., Stalking, and social and romantic functioning among adolescents and adults with autism spectrum disorder, "Journal of Autism and Developmental Disorders" 2007, nr 37.

Stokes M.A., Kaur A., High functioning autism and sexuality: A parental perspective, "Autism" 2005, nr 9 (3).

Van Son-Schoones N., Van Bilsen P., Sexuality and autism: a pilotstudy of parents, health care workers and autistic persons, "International Journal of Adolescent Medicine and Health" 1995, nr 8.

Winczura B., Dziecko z autyzmem, Terapia deficytów poznawczych a teoria umystu, Oficyna Wydawnicza „Impuls”, Kraków 2008.

Wojciechowska A., Pomiędzy dzieciństwem a dorosłościa - o dorastaniu osób z zespotem Aspergera, "Studia Edukacyjne” 2013a, nr 25.

Wojciechowska A., Wśród ludzi na własnych zasadach? O możliwościach i ograniczeniach w budowaniu relacji z rówieśnikami przez młodzież z zespotem Aspergera, "Studia Edukacyjne" 2013b nr 28.

Zielona-Jenek M., Chodecka A., Jestem dziewczynka, jestem chtopcem. Jak wspomagać rozwój seksualny dziecka, Gdańskie Wydawnictwo Psychologiczne, Gdańsk 2010. 